\title{
BOURDIEU AND HISTORICAL ANALYSIS
}




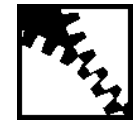

POLITICS, HISTORY, AND CULTURE

A series from the International Institute at the University of Michigan

SERIES EDITORS

George Steinmetz and Julia Adams

SERIES EDITORIAL ADVISORY BOARD

$\begin{array}{lll}\text { Fernando Coronil } & \text { Nancy Rose Hunt } & \text { Julie Skurski } \\ \text { Mamadou Diouf } & \text { Andreas Kalyvas } & \text { Margaret Somers } \\ \text { Michael Dutton } & \text { Webb Keane } & \text { Ann Laura Stoler } \\ \text { Geoff Eley } & \text { David Laitin } & \text { Katherine Verdery } \\ \text { Fatma Müge Göcek } & \text { Lydia Liu } & \text { Elizabeth Wingrove }\end{array}$

Sponsored by the International Institute at the University of Michigan and published by Duke University Press, this series is centered around cultural and historical studies of power, politics, and the state-a field that cuts across the disciplines of history, sociology, anthropology, political science, and cultural studies. The focus on the relationship between state and culture refers both to a methodological approach-the study of politics and the state using culturalist methods-and to a substantive one that treats signifying practices as an essential dimension of politics. The dialectic of politics, culture, and history figures prominently in all the books selected for the series. 


\section{BOURDIEU AND HISTORICAL ANALYSIS \\ EDITED BY PHILIP S. GORSKI}

DUKE UNIVERSITY PRESS

DURHAM AND LONDON 2013 
(C) 2013 Duke University Press

All rights reserved

Printed in the United States of America on acid-free paper @)

Typeset in Minion Pro by Keystone Typesetting

Library of Congress Cataloging-in-Publication Data appear on the last printed page of this book.

Chapter 9, “T. H. Marshall Meets Pierre Bourdieu: Citizens and Paupers in the Development of the U.S. Welfare State" by Chad Alan Goldberg, was originally published in Political Power and Social Theory 19 (2008), 83-116. (C) Emerald Group Publishing Limited, all rights reserved. 